89 累アレルギー患者の下気道

\author{
。矢島 洋, 奥田稳（和医大） \\ 海野 衡二 （旭川医大）
}

目的：吸入性下気道了レルギーの多くに舅汁中好 酸球增多，抗原舅誘発反応陽性など竇アレルギーの合 併を示唆する所見がみられるのをすで発表した。今 回は気管文喘息症状・既往のない鼠アレルギーのみの 症例の下氮道に佶機能検䄳・抗原誘発テストを行い, 下気道潜在的な病变が存在する加むるいは下気道加 感作されているかどうかを検討した。

方法：1）熱線流量計䘮用いて奥アレルギー 患者の肺活量 (FVC), \%肺活量 $(\% \mathrm{VC}), 1$ 秒量 $\left(F_{1} V_{1}\right) ， 1$ 秒率 $\left(F^{\prime} E V_{1} .0 \%\right)$, 最大呼気速度

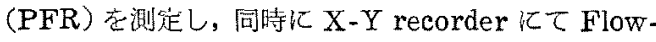
Volume 曲楾を記録, 肺活量の $75 \%, 50 \%, 25 \%$ での最大呼気趣度 $\left(\dot{V}_{75}, \dot{V}_{50}, \dot{V}_{25}\right)$ を求加た。

2）抗原ティスクによる舅内脬発前後に上記検查を行 い両者を比校し，また下颌道症状の有然在䝷察した。

3）抗原のネブライザーによる経鼠・経口的喷霧前媵

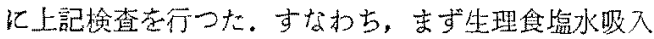
5 分, 10 分, 15 尔後任测定, ついで抗原液吸人 5 分, 10 分，15分後に测定比校し，古加世て症状の有無索 観察した。

成 綪：文管支喘息のない，主として HD を抗原 上する宜アレルギ一患者53名の各测定値の平均は FVC $4.14 \ell, \%$ VC $100.9 \%, \quad F E V_{1.0} \% 85.9 \%$, PFR $8.21 \mathrm{l} / \mathrm{sec}, \dot{V}_{75} 7.21 \mathrm{l} / \mathrm{sec}, \dot{V}_{50} 4.50 \mathrm{l} / \mathrm{sec}$, $\dot{\mathrm{V}}_{25} 1.86 \ell /$ sec. であつた. $\mathrm{FEV}_{1.0 \%}$ 但值 $(<70 \%)$ は 1 例屯なく，末梢気道の病態を表和す $V_{50}, V_{25}$ の低下例は $1 / 53 ， 2 / 53$ のみであつた。29例に抗原ディ

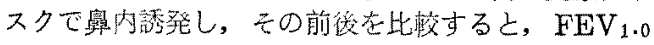
\%の低下例はなく, $\mathrm{V}_{50}, \mathrm{~V}_{25}$ 低下例は各々, 4 例 $(13.7 \%), 2$ 例 $(6.8 \%)$ ですつt. 喘息症状出現し た例はなかつた。抗原液で吸入誘発した場合ては，舅 内名らの場合， $\mathrm{FEV}_{1.0} \%$ 低下例はなく, $\mathrm{V}_{50}$ 低下例 1 例 $/ 13$ 例, $\cdot V 25$ 但下 6 例 $/ 13$ 例て， 口内上り誘発 した場合, $\mathrm{FEV}_{1.0} \%$ ， PER, $\mathrm{V}_{50}, \mathrm{~V}_{25}$ の低下は 各六, 約 $4 \%, 20 \%, 25 \%, 30 \sim 35 \%$ 前後であつ た。柽い腨息症状出現した例もみら机た。

結 論：気管支㟨息のない宜アレルギーのみの症例 で肺機能低下例は少なく，また胸部レントゲン写真て

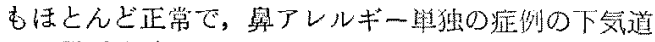

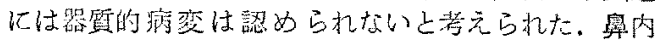
誘発した場合肺機能低下例は少なかつたが，一部に PFR, V $50 ， V_{25}$ が低下したので舅アレルギーの発

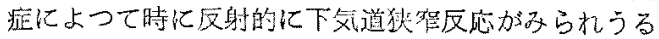

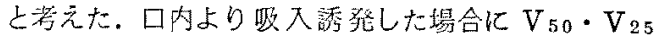
加20\%以上の症例に低下したことは，下気道の自覚

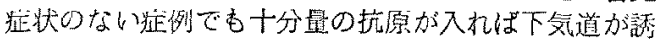
発され気管支喘息を皃症する可能性すあることが予 想された。

\section{0 気道における真菌過敏性の検討}

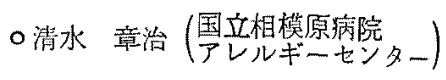

目的：気道のアレルギー性跃忠に真菌胞子がアレ ルゲンとして関与していることは古くから指摘されて いるが，ての分野の検討は室内塺や花粉などの抗原に 比較して，まだ十分明らかにされていない点加多い。

そこで当アレルギーセンターの過去 5 年間 (1971年 〜 1976年）におこなつた成人 4510 例の気管支喘息な いしは羁アレルギー患者について 15 㮔の重要真菌了 レルゲンエキスによる皮内反応成績を集計し，同時に 空中真菌調查成續と比较梌討したので報告する。

太法：誩断使用した真菌抗原エキスは市販鳥居 䌘エキス 5 種の他は Hollister-stier 社䌘である。

空中点菌胞子の梌索は standard pollen sampli$\mathrm{ng}$ device 用いて $1 \mathrm{~cm}^{2}$ 上に落下した胞子数を slide method を中心に主要真菌胞子につき調査をお こなつた。

成績ならびに結論：1）陽性率からみると Candida $54.9 \%$, Aspergilus $24.7 \%$, Trichophyton 16. 3\%, Penicillium 15.0\%, Cladosporium 13.1 $\% 6$, Alternaria $12.2 \%$, Cephalosporium $4.2 \%$, Sepedonium 3.9\%, Macrosporium 3.3\%, Epicoccum 3.2\%, Cephalothecium 3.0\%, Mucor 2.9\%, Fusarium 2.3\%, Botrytis 2.0\%, Pullularia $1.8 \%$ と空中飛散真菌胞子上りも人体常在ない

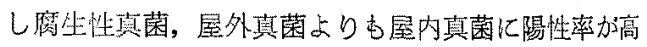
い結果定得大。

また不完全菌類のうち Epicoccum や Fusarium

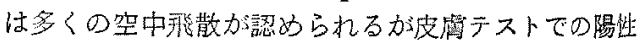
率が低く、アレルゲンとしての意義は少ないと考えら れる，2）季節的には Alternaria を除く之屋外棩 散真菌胞子の多塞上晹性率は汃ならずしも一致せず， このことは Alternaria 以外の屋外真菌は花粉類任 ぜ強い感作源となりえないでるうと思われる。

陽性率の上くに高い Candida 胞子加空中红我散士 るか否か㤬定見がないが，陽性率でも比较的季節的消 長怔少ない，3）年次的な变動加らは抗原似より多少

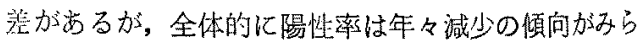
れた。 